\title{
Parathyroid Carcinoma pTis TNM Finding v8
}

National Cancer Institute

\section{Source}

National Cancer Institute. Parathyroid Carcinoma pT is TNM Finding v8. NCI Thesaurus. Code C141063.

Atypical parathyroid neoplasm (neoplasm of uncertain malignant potential). (from AJCC 8th Ed.) 